\title{
Invasion of fall armyworm Spodoptera frugiperda, a new invasive pest, alters native herbivore attack intensity and natural enemy diversity
}

\author{
AKHMAD RIZALI", OKTAVIYANI, SACHRISTY D.P.S. PUTRI, MEYGALINTANG DOANANDA, \\ ASTI LINGGANI \\ Department of Plant Pests and Diseases, Faculty of Agriculture, University of Brawijaya. Jl. Veteran, Malang 65145, Indonesia. \\ Tel./fax.: +62-341-575843. `email: arizali@ub.ac.id
}

Manuscript received: 25 June 2021. Revision accepted: 27 July 2021

\begin{abstract}
Rizali A, Oktaviyani, Putri SDPS, Doananda M, Linggani A. 2021. Invasion of fall armyworm Spodoptera frugiperda, a new invasive pest, alters native herbivore attack intensity and natural enemy diversity. Biodiversitas 22: 3482-3488. A new invasive alien pest, fall armyworm Spodoptera frugiperda has been reported widely spread in Indonesia since 2019 and can cause a serious problem in maize cultivation. Its invasion of new habitat may severely impact not only maize production but also native biodiversity including other native pests. This research was aimed to investigate the effect of $S$. frugiperda invasion on the attack intensity of native herbivores as well as the diversity of natural enemies in maize fields. Field research was conducted in twelve maize fields spread across the district of Malang, Kediri, and Batu, East Java, Indonesia. In each maize field, sampling of S. frugiperda and other insects was conducted by the hand-picking method within four transects with each transect consisting of 100 plants. The results found five species of lepidopteran pests including S. frugiperda, Ostrinia furnacalis, Helicoverpa armigera, Mycalesis sp, and Chrysodeixes sp. S. frugiperda was found with higher attack intensity than other lepidopteran pests. Based on the analysis, the attack intensity of $S$. frugiperda had a positive relationship with pesticide application and was marginally correlated with plant age and elevation. The infestation of $S$. frugiperda significantly reduced the attack intensity of other lepidopteran pests as well as the diversity of natural enemies, especially predators. Two native species of parasitoid wasps, Telenomus sp and Mymaridae sp were recorded parasitizing the eggs of S. frugiperda. In conclusion, the infestation of $S$. frugiperda causes biotic homogenization in the maize field by directly compete with other lepidopteran pests and indirectly eliminate the natural enemy diversity.
\end{abstract}

Keywords. Invasive species, lepidopteran pest, maize field, parasitoid, predator

\section{INTRODUCTION}

The invasion of invasive alien insects in new regions or habitats can cause a negative effect on native biodiversity (McGeoch et al. 2015; Hill et al. 2016). Several wellknown mechanisms by which alien insects impact native biodiversity are competition (Rowles and O'Dowd 2007), predation (Roy and Brown 2015), disease transmission (Jacobi et al. 2013), and herbivory (Herms and McCullough 2014). A review by McGeoch et al. (2015) presented that herbivory is the most frequent mechanism and among other insect orders, Coleoptera and Hemiptera are the main orders that contributing to this impact mechanism. For instance, Agrilus planipennis or emerald ash borer (Coleoptera: Buprestidae) can cause millions of ash trees to be killed in North America and also cause changes to understorey environment as well as a reduction in food sources for other arthropod herbivores (Herms and McCullough 2014). In addition, the invasion of invasive insects besides negatively affects the environment, also significantly affects socio-economy such as damage to forestry, agriculture, as well as human health (McGeoch et al. 2015). Therefore, more efforts are needed to mitigate and adapt to the effects of invasive insects due to can affect food security in a country (Cook et al. 2011).

Although Indonesia, as one of the countries in the world with the level of invasion threat by insects is relatively low
(Paini et al. 2016), the invasion of invasive insects can severely affect native biodiversity, environment, and socioeconomy. However, as a tropical country and with high biodiversity and endemism (Myers et al. 2000), Indonesia is vulnerable to the invasion of invasive pests (Paini et al. 2016). In 2019, Indonesia was invaded by a new invasive alien pest, Spodoptera frugiperda (J.E. Smith) (Lepidoptera: Noctuidae). S. frugiperda or fall armyworm was firstly recorded in West Sumatera (Trisyono et al. 2019; Sartiami et al. 2020) and then spread to other islands including Java Island in the same year (Maharani et al. 2019; Asfiya et al. 2020). S. frugiperda is native to America and since 2016, it has been aggressively moving over eastwards, spread widely across Africa, and introduce for the first time in Asia in mid-2018 in India. In January of 2019, S. frugiperda has spread to China, Myanmar, and Thailand before arriving in Indonesia. As a polyphagous insect, $S$. frugiperda can cause serious damage to the maize plant and cause high economic losses. While economic losses in Indonesia have not yet been estimated, the infestation of $S$. frugiperda has the potential to cause maize yield losses of 8.3 to 20.6 million tonnes annually with valued at between US $\$ 2.5$ to US $\$ 6.2$ billion without control efforts (FAO \& CABI 2019).

Besides the effect on economic loss, the invasion of $S$. frugiperda may also affect native biodiversity. In Africa, the infestation of $S$. frugiperda can affect the native 
biodiversity by reducing both native insect pests and other insect communities (Sokame et al. 2021b; Sokame et al. 2021a). Larvae of $S$. frugiperda have the ability to compete (intraspecies competition) and predate other larvae (cannibalism) (Chapman et al. 2000; Ren et al. 2020). S. frugiperda larvae can also reduce the larvae of other lepidopteran pests through interference competition and predation (Wiseman and McMillian 1969; Song et al. 2021). In addition, the infestation of $S$. frugiperda was also reported to have a negative effect on natural enemies especially parasitoids by decrease the parasitism rate on native stem borers (Sokame et al. 2021b). However, as a consequence of the presence of new species in a habitat, $S$. frugiperda can interact with native species both of predators and parasitoids. It has been documented in Africa that $S$. frugiperda can be parasitized by a native parasitoid wasp, Cotesia icipe (Hymenoptera: Braconidae) which is the dominant parasitoid of $S$. frugiperda larvae in Kenya, Ethiopia, and Tanzania (Sisay et al. 2018).

The objective of this research was to investigate the effect of the invasion of $S$. frugiperda on the attack intensity of native lepidopteran pests and the diversity of natural enemies. The research was conducted on several maize (Zea mays) fields in East Java. It has been documented that maize in Indonesia has main lepidopteran pests such as Asian corn borer, Ostrinia furnacalis (Guenée) (Lepidoptera: Crambidae), and corn earworm Helicoverpa armigera (Hübner) (Lepidoptera: Noctuidae) (Kalshoven 1981). The invasion of $S$. frugiperda may have a negative impact on the attack intensity of other lepidopteran pests due to its feeding behavior overlap with other lepidopteran pests such as feed on foliage, stem, and also ears of the maize plant. Thus, this research hypothesizes that the invasion of $S$. frugiperda will reduce the attack intensity of other lepidopteran pests and also reduce the diversity of natural enemies in maize fields.

\section{MATERIALS AND METHODS}

\section{Research location and transect selection}

The research was conducted in twelve maize fields located in different villages spread across three districts i.e., Malang, Batu, and Kediri within the province of East Java (Figure 1). Maize fields were chosen by considering the minimum area is $800 \mathrm{~m}^{2}$, minimum plant age is 3 weeks after planting, and minimum distance from other maize fields is $2 \mathrm{~km}$. In each maize field, four transects were determined as a sampling unit with each transect consisting of 100 maize plants. In addition, interviews with the owner of the maize field were also conducted to provide information about cultivation techniques including the size of a maize field, maize variety, plant age, and intensity of pesticide application (Table 1).

\section{Sampling of lepidopteran pests and natural enemies}

The lepidopteran pests and natural enemies were sampled from January to March 2020 using a hand-picking method. The damaged symptoms due to lepidopteran larvae were also observed that can be distinguished especially between $S$. frugiperda and other lepidopteran pests. For instance, the damages of $S$. frugiperda on maize leaves is indicated by the presence of feces and the window-like symptom on the whorl with the size of holes are greater than O. furnacalis (Trisyono et al. 2019). In each maize field, sampling and observation were carried out three times in the vegetative phase ( 3 and 5 weeks old) and generative phase ( 7 weeks old). Lepidopteran pests and natural enemies were sampled and observed on each maize plant for a maximum of 30 minutes per transect. The attack symptoms were also noted to get the data of attack intensity of each lepidopteran pest. In this research, non-pests of lepidopteran were not found during the observation in all maize fields. Eggs and larvae of lepidopteran pests were collected and placed individually into a plastic container and were brought to the laboratory. Eggs and larvae were observed daily to record the parasitoid or adult emergence.

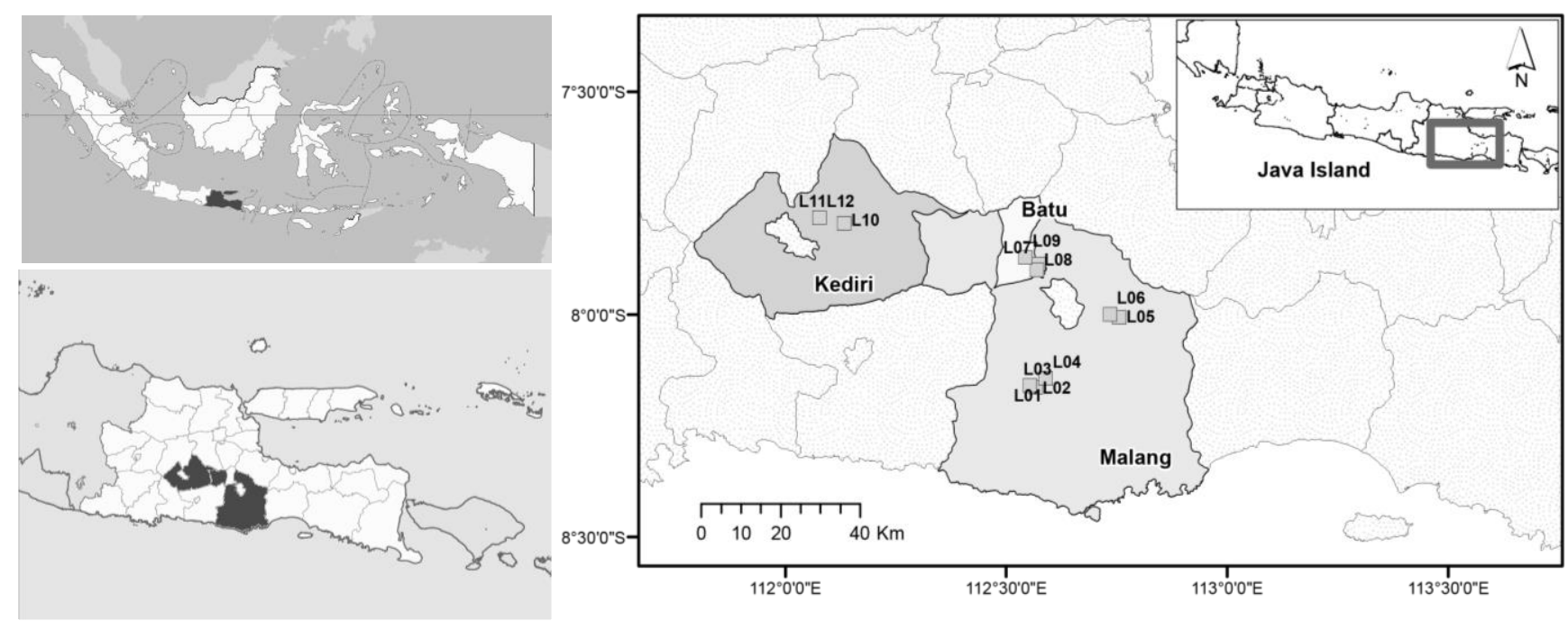

Figure 1. Map of research location in twelve maize fields in East Java, Indonesia. The letter and number refer to the plot code listed in Table 1 
Table 1. Characteristic of research location located in twelve different maize fields in East Java, Indonesia

\begin{tabular}{lllclcc}
\hline Plot code & District & Village & $\begin{array}{c}\text { Elevation } \\
(\mathbf{m} \text { asl } *)\end{array}$ & Variety & Field size $\left(\mathbf{m}^{2}\right)$ & Pesticide application** \\
\hline L01 & Malang & Sukorejo & 358 & Lokal super & 2,500 & 1 \\
L02 & Malang & Kemiri & 337 & Mentari & 2,500 & 2 \\
L03 & Malang & Pasanggrahan & 340 & Lokal super & 5,000 & 0 \\
L04 & Malang & Poncokusumo & 563 & Talenta & 1,500 & 4 \\
L05 & Malang & Tumpang & 595 & Talenta & 2,500 & 15 \\
L06 & Malang & Bokor & 552 & Pioner & 5,500 & 1 \\
L07 & Batu & Tawang Argo & 710 & Pertiwi & 2,000 & 10 \\
L08 & Batu & Krajan & 658 & Talenta & 2,000 & 20 \\
L09 & Batu & Pandanrejo & 852 & Talenta & 800 & 10 \\
L10 & Kediri & Tiru Lor & 131 & BISI-99 & 3,500 & 0 \\
L11 & Kediri & Menang & 143 & Perkasa & 1,050 & 4 \\
L12 & Kediri & Kawedusan & 103 & Talenta & 2,800 & 18 \\
\hline
\end{tabular}

Note: * asl: above sea level; **: number of pesticide applications per planting season

Whilst, the specimens of natural enemies were preserved in the plastic vials with $70 \%$ alcohol for later identification in the laboratory. All specimens were identified to morphospecies level based on their morphological characteristics using available references e.g. Borror et al. (1996), Bolton (1994), and Goulet and Huber (1993).

\section{Data Analysis}

To calculate the attack intensity (\%) of each lepidopteran pest was based on the number of attacked plants divided by the total number of observed plants $\mathrm{x}$ $100 \%$. Multiple regression analysis was used to analyze the relationship between attack intensity of lepidopteran pests and maize field characteristics i.e., elevation, plant age, and pesticide application. In addition, regression analysis was used to analyze the relationship between the invasion of $S$. frugiperda and other lepidopteran pests as well as natural enemies. All analyses were performed using R statistical software (R Core Team 2020).

\section{RESULTS AND DISCUSSION}

\section{Diversity and attack intensity of lepidopteran pests in maize fields}

The research recorded five species of lepidopteran pests attacking maize plants from twelve locations i.e., $S$. frugiperda (Family Noctuidae), O. furnacalis (Family Crambidae), H. armigera (Family Noctuidae), Mycalesis sp or green-horned caterpillar (Family Nymphalidae), and Chrysodeixes sp or corn semi-looper (Family Noctuidae). $S$. frugiperda was almost found in all maize fields except in Pasanggrahan village and a higher attack intensity (average 4\%-26.3\%) than other lepidopteran pests (Table 2). Similar to $S$. frugiperda, $H$. armigera was also almost found in all locations except Kemiri village (Table 2). According to sampling time or plant age, $H$. armigera, as well as $O$. furnacalis, did not find in 3 weeks after planting (WAP), while $S$. frugiperda was found in all sampling times (Figure 2). The lowest occurrence and attack intensity of lepidopteran pests are by Chrysodeixes sp that only found in two locations with average attack intensity between $0.1 \%-1.5 \%$, and did not record in plant age of 7 WAP.

As the main lepidopteran pests of maize, $O$. furnacalis and $H$. armigera were commonly recorded in maize fields in Indonesia. O. furnacalis feed on the foliage, but then move into the stems while $H$. armigera feed on both silk and within the ears (Capinera 2008; Maharani et al. 2019). In this research, $S$. frugiperda was also recorded as a new invasive species to invade maize fields in East Java. After being firstly reported in 2019 (Trisyono et al. 2019), $S$. frugiperda was intensively surveyed and in the same year have been detected in West Java (Maharani et al. 2019; Asfiya et al. 2020). In early 2020, when this research was conducted, S. frugiperda has been infested the maize fields in Kediri, Malang, and Batu, East Java, although certain maize fields are still not invaded by this pest. As a new pest, the attack intensity of $S$. frugiperda was found higher than other lepidopteran pests. However, the attack intensity in East Java was lower than in West Java that can reach $78 \%$ to $100 \%$ (Asfiya et al. 2020).

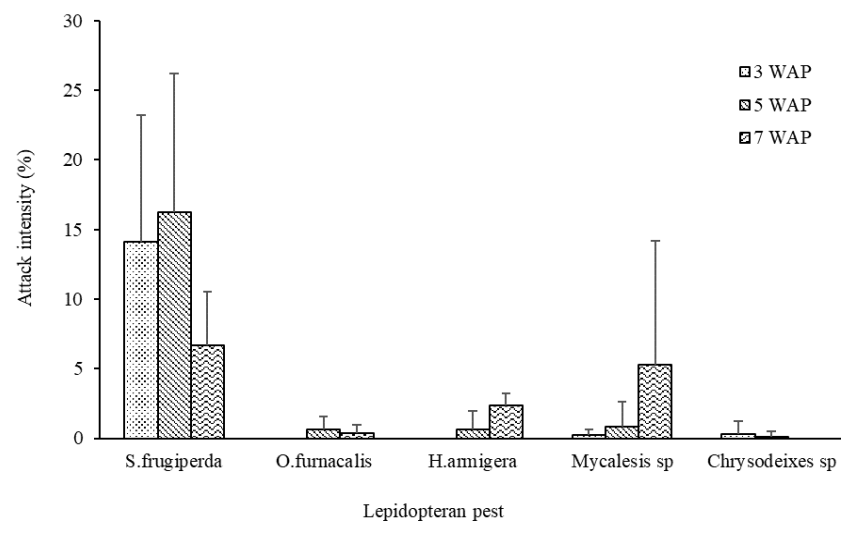

Figure 2. Difference of lepidopteran pest attack intensity (mean \pm $\mathrm{SD}$ ) between plant age of maize. WAP: weeks after planting 
Table 2. Attack intensity (means \pm SD) of lepidopteran pests from different maize fields

\begin{tabular}{lllllll}
\hline Code & Village & S. frugiperda & O. furnacalis & H. armigera & Mycalesis sp & Chrysodeixes sp \\
\hline L01 & Sukorejo & $4.0 \pm 1.8$ & $0.9 \pm 0.9$ & $1.8 \pm 1.8$ & $7.8 \pm 11.4$ & 0 \\
L02 & Kemiri & $4.7 \pm 1.4$ & $0.5 \pm 0.9$ & 0 & $8.3 \pm 13.0$ & 0 \\
L03 & Pasanggrahan & 0 & 0 & $1.1 \pm 1.9$ & $7.1 \pm 6.5$ & 0 \\
L04 & Poncokusumo & $10.3 \pm 3.8$ & $0.5 \pm 0.9$ & $1.8 \pm 1.8$ & 0 & 0 \\
L05 & Tumpang & $17.8 \pm 7.0$ & $1.0 \pm 1.0$ & $0.8 \pm 1.4$ & 0 & 0 \\
L06 & Bokor & $9.1 \pm 4.4$ & $1.2 \pm 1.1$ & $0.9 \pm 1.6$ & 0 & 0 \\
L07 & Tawang Argo & $20.2 \pm 8.2$ & 0 & $1.0 \pm 1.3$ & 0 & $0.1 \pm 0.1$ \\
L08 & Krajan & $26.3 \pm 12.2$ & 0 & $0.8 \pm 1.4$ & 0 & 0 \\
L09 & Pandanrejo & $17.7 \pm 7.0$ & 0 & $0.9 \pm 1.6$ & 0 & 0 \\
L10 & Tiru Lor & $16.9 \pm 6.6$ & 0 & $0.8 \pm 1.4$ & 0 & 0 \\
L11 & Menang & $9.8 \pm 4.2$ & 0 & $0.8 \pm 1.4$ & $0.4 \pm 0.5$ & 0 \\
L12 & Kawedusan & $11.6 \pm 4.3$ & 0 & $1.1 \pm 1.9$ & $1.7 \pm 2.9$ & $1.5 \pm 1.6$ \\
\hline
\end{tabular}

The potential of damage level by arthropod pests in maize is about $14-17 \%$ worldwide (Capinera 2008), thus with such a level of damage, S. frugiperda becomes the most destructive pest than other lepidopteran pests. The damage due to $S$. frugiperda does not always cause plant mortality but always causes significant yield reduction ( $28 \%$ per plant) especially when the plants were infested during the first to second week after germination (Evans and Stansly 1990). Research by Niassy et al. (2021) also found that the infestation of $S$. frugiperda was varied between crop phenology with infestation being high at the vegetative stages of the maize. With the actual level of attack intensity of $S$. frugiperda, it is needed a comprehensive approach to mitigating the damaging effect of the infestation of this pest in maize fields.

The results of multiple linear regression showed that the attack intensity of $S$. frugiperda had a positive relationship with the intensity of pesticide application $(\mathrm{P}=0.001$; Table 3 ). Increasing the intensity of pesticide application in maize fields tends to increase the attack intensity of $S$. frugiperda. It is possibly due to the invaded species has already been resistant to insecticide since from the origin area that had been reported e.g. by Yu (1992) and Carvalho et al. (2013). In contrast, $O$. furnacalis $(\mathrm{P}=0.256)$ and $H$. armigera $(\mathrm{P}=0.879)$ were not related to pesticide application (Table
3). Although pesticide application can cause resistance to those pests, the resistance may in the lower level than $S$. frugiperda. A study by Torres-Vila et al. (2002) revealed that insecticide resistance in $H$. armigera occurs but lower depend on the geographical regions. In relation to the elevation factor, the attack intensity of $S$. frugiperda, $H$. armigera, and $O$. furnacalis was not correlated with the elevation of a maize field. Elevation which is also related to temperature tends to have an effect on the life-history of lepidopteran pests than the attack intensity that had been shown for O. furnacalis (Xiao et al. 2016). In addition, plant age had a positive relationship with the attack intensity of $H$. armigera $(\mathrm{P}<0.001)$ but not with $O$. furnacalis $(\mathrm{P}=0.120)$. As the corn earworm, H. armigera prefers feeding on the ear (Capinera 2008), thus the attack intensity was occurred in 5 WAP and increase in 7 WAP (Figure 2). In other crops such as tomato (Solanum lycopersicum), the infestation of $H$. armigera also revealed had a relationship with plant phenology (Torres-Vila et al. 2003). The attack intensity of $S$. frugiperda was also tended to relate with plant age, although with marginal significance $(\mathrm{P}=0.053)$. Based on Trisyono et al. (2019), the damage by $S$. frugiperda was related to the plant age and the larvae prefer to infest the young maize.

Table 3. Multiple regression relating attack intensity of lepidopteran pests to plant age, elevation, and pesticide application as predictors. Significance level $* *: \mathrm{P}<0.01$

\begin{tabular}{lcccccccccc}
\hline \multirow{2}{*}{ Variable } & \multicolumn{2}{c}{ S. frugiperda } & \multicolumn{2}{c}{$\boldsymbol{O}$. furnacalis } & \multicolumn{2}{c}{$\boldsymbol{H}$. armigera } & \multicolumn{2}{c}{ Mycalesis sp } & \multicolumn{2}{c}{ Chrysodeixes sp } \\
\cline { 2 - 11 } & Estimate & $\mathbf{P}$ & Estimate & $\mathbf{P}$ & Estimate & $\mathbf{P}$ & Estimate & P & Estimate & P \\
\hline (Intercept) & 10.573 & 0.017 & -0.256 & 0.533 & -2.024 & 0.001 & -0.277 & 0.933 & 0.753 & 0.015 \\
Age & -0.133 & 0.053 & 0.010 & 0.120 & 0.059 & $<0.001^{* *}$ & 0.097 & 0.068 & -0.008 & 0.089 \\
Elevation & 0.010 & 0.067 & 0.000 & 0.393 & 0.000 & 0.885 & -0.003 & 0.394 & -0.001 & $0.005^{* *}$ \\
Pesticide & 0.632 & $0.001^{* *}$ & -0.019 & 0.256 & -0.004 & 0.879 & -0.171 & 0.207 & 0.039 & $0.002^{* *}$ \\
\hline
\end{tabular}




\section{Effect of $S$. frugiperda invasion on attack intensity of native lepidopteran pests and diversity of natural enemies}

Based on regression analysis, the attack intensity of $S$. frugiperda had a negative effect on the attack intensity of H. armigera $(\mathrm{P}=0.016)$ and Mycalesis $\mathrm{sp}(\mathrm{P}=0.009)$ but did not have an effect on $O$. furnacalis $(\mathrm{P}=0.519)$ and Chrysodeixes sp ( $\mathrm{P}=0.775)$ (Table 4).

Research by Sokame et al. (2021b) also revealed that the introduction of the $S$. frugiperda in maize fields was strongly related to the decrease of the abundance of stemborers in Kenya. In this research, S. frugiperda and $O$. furnacalis did not find co-exist in the same maize plant, even with $H$. armigera. This is perhaps due to the overlap of feeding behavior between $S$. frugiperda and other lepidopteran pests. According to Trisyono et al. (2019), $O$. furnacalis has the same feeding behavior as $S$. frugiperda that was initially fed on the foliage and then move into the stems. With this behavior, S. frugiperda can potentially replace the presence of $O$. furnacalis. As invasive species, besides the ability on intraspecific competition (Morrill and Greene 1973; Labatte 1993), larvae of S. frugiperda has also ability to reduce and replace other lepidopteran larvae by interference competition and predation (Wiseman and McMillian 1969; Song et al. 2021). The competition and displacement could be occurred due to $S$. frugiperda and stemborer share the same maize resource, as previously demonstrated among lepidopteran stem borers in laboratory and greenhouse (Ntiri et al. 2016; Ntiri et al. 2017) as well as in field experiments (Ntiri et al. 2019).

This research also observed the diversity of natural enemies both predators and parasitoids that are associated with $S$. frugiperda as well as other lepidopteran pests. In total, 17 species of predators and two species of parasitoid wasps were recorded from all locations (Table 5). Predators are grouped into three taxa i.e., ants, beetles, and spiders, while parasitoid wasps were recorded only from the eggs and were not found from the larvae of S. frugiperda. Two species of egg parasitoids, Telenomus sp., and Mymaridae sp. are native parasitoids that can parasitize the eggs of $S$. frugiperda (Figure 3). Based on the regression analysis, the invasion of $S$. frugiperda had a negative effect on the diversity of predators $(\mathrm{P}=0.031$; Table 4$)$. Parasitoids were excluded in the analysis due to only being found in three locations. Although the mechanism is not clear yet, the decrease of predator diversity was perhaps related to the decrease of native pests as a consequence of the invasion of
S. frugiperda. It has been shown for parasitoids that the invasion of $S$. frugiperda was reported to have a negative effect on parasitoids especially decrease the parasitism rate of stem borers (Sokame et al. 2021b). This is due to the abundance of parasitoids that may follow the abundance of pests (Sokame et al. 2021a). This pattern accepts the hypothesis that interaction diversity is linked to the LotkaVolterra prey-predator system, which is the positive correlation between pest abundance and natural enemies (Boukal and Krivan 1999).

This research was conducted around a year after the invasion of $S$. frugiperda in Indonesia and it recorded a new association between two species of native parasitoids and S. frugiperda in East Java. Although this research was not recorded yet, there will be a possibility of the association of native parasitoids that parasitize the larvae of S. frugiperda. In Africa, a native parasitoid, Cotesia icipe (Hymenoptera: Braconidae) has been recorded to be the dominant parasitoid of $S$. frugiperda larvae in Kenya, Ethiopia, and Tanzania (Sisay et al. 2018). Even, other local parasitoids such as Cotesia flavipes and Cotesia sesamiae can parasitize the larvae of S. frugiperda under laboratory conditions, although failed to develop (Sokame et al. 2020). As a consequence of these interferences, it has an effect on a pre-existing biological control process of $S$. frugiperda (Desurmont et al. 2014; Chabaane et al. 2015). This condition might be an advantage for $S$. frugiperda exhibit significant outbreaks due to lower demographic pressure from natural enemies (Abram et al. 2014).
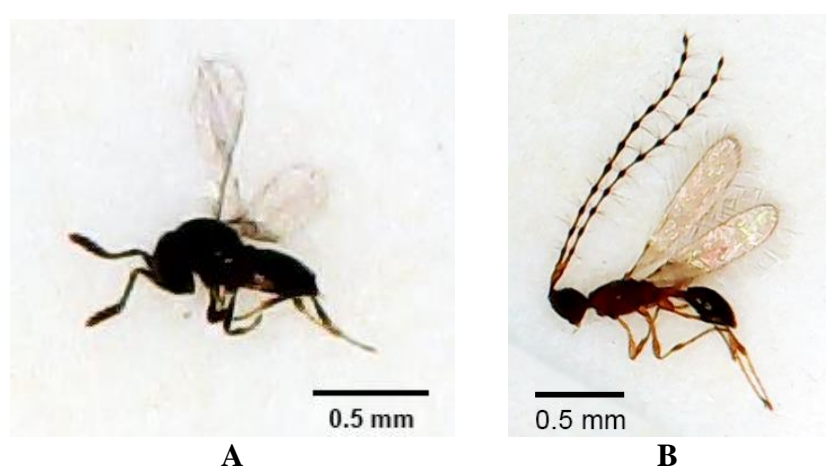

Figure 3. Parasitoid wasps were found emerging from the eggs of S. frugiperda. A. Telenomus sp., B. Mymaridae sp.

Table 4. Relationship between attack intensity of native lepidopteran pests and species richness of predators and $S$. frugiperda attack intensity. Significance level *: $\mathrm{P}<0.05, * *: \mathrm{P}<0.01$

\begin{tabular}{|c|c|c|c|c|c|c|c|c|c|c|}
\hline \multirow{2}{*}{ Variable } & \multicolumn{2}{|c|}{ O. furnacalis } & \multicolumn{2}{|c|}{ H. armigera } & \multicolumn{2}{|c|}{ Mycalesis sp } & \multicolumn{2}{|c|}{ Chrysodeixes sp } & \multicolumn{2}{|c|}{ Predator } \\
\hline & Estimate & $\mathbf{P}$ & Estimate & $\mathbf{P}$ & Estimate & $\mathbf{P}$ & Estimate & $\mathbf{P}$ & Estimate & $\mathbf{P}$ \\
\hline (Int & 0.444 & 0.030 & 1.752 & 0.000 & 5.410 & 0.001 & 0.093 & 0.584 & 5.611 & 0.000 \\
\hline S.frugiperda & -0.008 & 0.519 & -0.061 & $0.016^{*}$ & -0.268 & $0.009 * *$ & 0.003 & 0.775 & -0.074 & $0.031 *$ \\
\hline
\end{tabular}


Table 5. Morphospecies and individual number of predators and parasitoids from different maize fields. The letter and number of maize fields refer to the plot code listed in Table 1

\begin{tabular}{|c|c|c|c|c|c|c|c|c|c|c|c|c|}
\hline \multirow{2}{*}{ Morphospecies } & \multicolumn{12}{|c|}{ Maize fields } \\
\hline & L01 & L02 & L03 & L04 & L05 & L06 & L07 & L08 & L09 & L10 & L11 & L12 \\
\hline \multicolumn{13}{|l|}{ Predator-Ants } \\
\hline Anoplolepis gracilipes & 57 & 12 & 0 & 0 & 4 & 0 & 0 & 0 & 61 & 12 & 0 & 0 \\
\hline Dolichoderus sp & 0 & 0 & 0 & 0 & 0 & 37 & 32 & 8 & 3 & 113 & 0 & 38 \\
\hline Pheidole sp1 & 0 & 21 & 26 & 0 & 0 & 0 & 0 & 0 & 34 & 5 & 0 & 12 \\
\hline Pheidole sp2 & 0 & 2 & 2 & 0 & 0 & 0 & 0 & 0 & 0 & 0 & 0 & 0 \\
\hline Polyrhachis sp & 0 & 0 & 0 & 4 & 0 & 0 & 0 & 0 & 0 & 0 & 153 & 0 \\
\hline Tapinoma $\mathrm{sp}$ & 0 & 0 & 0 & 0 & 0 & 0 & 0 & 5 & 20 & 0 & 0 & 0 \\
\hline \multicolumn{13}{|l|}{ Predator-Beetles } \\
\hline Micraspis sp & 1 & 7 & 3 & 6 & 6 & 8 & 0 & 1 & 1 & 1 & 0 & 2 \\
\hline Menochilus sexmaculatus & 5 & 13 & 7 & 21 & 11 & 24 & 11 & 20 & 10 & 27 & 15 & 19 \\
\hline Harmonia sp & 3 & 0 & 2 & 0 & 1 & 1 & 1 & 4 & 3 & 1 & 9 & 4 \\
\hline \multicolumn{13}{|l|}{ Predator-Spiders } \\
\hline Amaurobiidae sp & 0 & 0 & 0 & 0 & 0 & 0 & 0 & 0 & 0 & 1 & 2 & 2 \\
\hline Clubionidae $\mathrm{sp}$ & 1 & 1 & 1 & 5 & 3 & 15 & 4 & 1 & 3 & 9 & 5 & 4 \\
\hline Gnaphosidae sp1 & 0 & 0 & 0 & 0 & 1 & 0 & 0 & 3 & 0 & 0 & 0 & 0 \\
\hline Gnaphosidae sp2 & 0 & 0 & 0 & 0 & 0 & 0 & 1 & 0 & 7 & 0 & 0 & 0 \\
\hline Lycosidae $\mathrm{sp} 1$ & 1 & 1 & 1 & 0 & 0 & 0 & 0 & 0 & 0 & 11 & 8 & 1 \\
\hline Lycosidae sp2 & 2 & 0 & 0 & 5 & 2 & 9 & 5 & 0 & 1 & 0 & 0 & 0 \\
\hline Miturgidae sp1 & 1 & 2 & 0 & 0 & 0 & 0 & 0 & 0 & 0 & 0 & 0 & 0 \\
\hline Miturgidae sp2 & 0 & 1 & 2 & 0 & 0 & 0 & 4 & 0 & 1 & 0 & 0 & 0 \\
\hline \multicolumn{13}{|l|}{ Parasitoid wasp } \\
\hline Telenomus $\mathrm{sp}$ & 0 & 0 & 0 & 74 & 0 & 0 & 0 & 0 & 1241 & 0 & 0 & 45 \\
\hline Mymaridae sp & 0 & 0 & 0 & 0 & 0 & 0 & 0 & 0 & 1 & 0 & 0 & 0 \\
\hline
\end{tabular}

In conclusion, the invasion of $S$. frugiperda can reduce the attack intensity of native lepidopteran pests and also reduced the diversity of natural enemies especially predators. S. frugiperda can co-inhabit with native lepidopteran pests as an additional pest in maize fields across East Java. Since this study was conducted only a year after the introduction of $S$. frugiperda, further research will be needed to confirm the effect on local biodiversity as well as understand the interaction complexity with native natural enemies. The agroecological approach can be adopted to manage the infestation of S. frugiperda in new invaded habitat (Harrison et al. 2019). The management scale should be considered due to agricultural intensification at the landscape scale will be an advantage for S. frugiperda (Emery et al. 2021). In addition, intercropping maize with other crops should also be carefully counted due to intercropping with the wrong crop such as cassava (Manihot esculenta) may increase in $S$. frugiperda infestation due to encourages feeding and oviposition of the invasive pest on maize (Nwanze et al. 2021).

\section{ACKNOWLEDGMENTS}

We thank the twelve maize field farmers for providing access to their fields for this study. We also thank Novita Yuniasari, Nely Yuliastanti, Muhamad Ari Bachtiar, and Emha Dwi Rifqi Rafid, who provided support during the field research.

\section{REFERENCES}

Abram PK, Gariepy TD, Brodeur J. 2014. An invasive stink bug as an evolutionary trap for an indigenous egg parasitoid. Biol Invasions 16 : 1387-1395. DOI: 10.1007/s10530-013-0576-y.

Asfiya W, Subagyo VNO, Dharmayanthi AB, Fatimah, Rachmatiyah R. 2020. Attack intensity of Spodoptera frugiperda J.E. Smith (Lepidoptera: Noctuidae) on maize crops in Garut and Tasikmalaya Regencies, West Java. J Entomol Indones 17: 163-167. DOI: 10.5994/jei.17.3.163.

Bolton B. 1994. Identification Guide to the Ant Genera of the World, Harvard University Press, Cambridge, USA.

Borror D, Triplehorn CH, Johnson NF. 1996. An Introduction to the Study of Insects, 6th ed. Saunders College Publishing, Philadelphia, USA.

Boukal DS, Krivan V. 1999. Lyapunov functions for Lotka-Volterra predator-prey models with optimal foraging behavior. J Math Biol 39: 493-517. DOI: $10.1007 / \mathrm{s} 002850050009$.

Capinera JL. 2008. Maize (corn) pests and their management. In: Capinera JL (eds). Encyclopedia of Entomology. Springer, Dordrecht.

Carvalho RA, Omoto C, Field LM, Williamson MS, Bass C. 2013. Investigating the molecular mechanisms of organophosphate and pyrethroid resistance in the fall armyworm Spodoptera frugiperda. PLoS ONE 8: e62268. DOI: 10.1371/journal.pone.0062268.

Chabaane Y, Laplanche D, Turlings TCJ, Desurmont GA. 2015. Impact of exotic insect herbivores on native tritrophic interactions: a case study of the African cotton leafworm, Spodoptera littoralis, and insects associated with the field mustard Brassica rapa. J Ecol 103: 109-117. DOI: $10.1111 / 1365-2745.12304$.

Chapman JW, Williams T, Martínez AM, Cisneros J, Caballero P, Cave RD, Goulson D. 2000. Does cannibalism in Spodoptera frugiperda (Lepidoptera: Noctuidae) reduce the risk of predation? Behav. Ecol Sociobiol 48: 321-327. DOI: 10.1007/s002650000237.

Desurmont GA, Harvey J, van Dam NM, Cristescu S, Schiestl FP, Cozzolino S, Anderson P, Larsson MC, Kindlmann P, Danner H, Turlings TCJ. 2014. Alien interference: disruption of infochemical networks by invasive insect herbivores. Plant, Cell Environ. 37: 18541865. DOI: $10.1111 /$ pce. 12333 . 
Emery SE, Jonsson M, Silva H, Ribeiro A, Mills NJ. 2021. High agricultural intensity at the landscape scale benefits pests, but low intensity practices at the local scale can mitigate these effects. Agric Ecosyst Environ 306: 107199. DOI: 10.1016/j.agee.2020.107199.

Evans DC, Stansly PA. 1990. Weekly economic injury levels for fall armyworm (Lepidoptera: Noctuidae) infestation of corn in lowland Ecuador. J Econ Entomol 6: 2452-2454. DOI: 10.1093/jee/83.6.2452.

Food and Agriculture Organization of the United Nations (FAO), CAB International (CABI). 2019. Community-Based Fall Armyworm (Spodoptera frugiperda) Monitoring, Early Warning and Management: Training of Trainers Manual, First Edition, FAO and CABI, Rome, Italy.

Goulet H, Huber JT. 1993. Hymenoptera of the World: An Identification Guide to Families. Canada Communication Group Publishing, Ottawa.

Harrison RD, Thierfelder C, Baudron F, Chinwada P, Midega C, Schaffner U, van den Berg J. 2019. Agro-ecological options for fal armyworm (Spodoptera frugiperda JE Smith) management: providing low-cost, smallholder friendly solutions to an invasive pest. J Environ Manage 243: 318-330. DOI: 10.1016/j.jenvman.2019.05.011

Herms DA, McCullough DG. 2014. Emerald ash borer invasion of North America: history, biology, ecology, impacts, and management. Annu Rev Entomol 59: 13-30. DOI: 10.1146/annurev-ento-011613-162051.

Hill MP, Clusella-Trullas S, Terblanche JS, Richardson DM. 2016 Drivers, impacts, mechanisms and adaptation in insect invasions. Biol Invasions 18: 883-891. DOI: 10.1007/s10530-016-1088-3.

Jacobi WR, Koski RD, Negron JF. 2013. Dutch elm disease pathogen transmission by the banded elm bark beetle Scolytus schevyrewi. For Pathol 43: 232-237. DOI: 10.1111/efp.12023.

Kalshoven LGE. 1981. The Pests of Crops in Indonesia, Ichtiar Baru, Jakarta.

Labatte JM. 1993. Within-plant distribution of fall armyworm (Lepidoptera: Noctuidae) larvae on corn during whorl-stage infestation. Fla. Entomol. 76: 437-447. DOI: 10.2307/3495644.

Maharani Y, Dewi VK, Puspasari LT, Rizkie L, Hidayat Y, Dono D. 2019. Cases of fall armyworm Spodoptera frugiperda J. E. Smith (Lepidoptera: Noctuidae) attack on maize in Bandung, Garut, and Sumedang District, West Java. J Cropsaver 2: 38-46. DOI: 10.24198/cropsaver.v2i1.23013.

McGeoch MA, Lythe MJ, Henriksen MV, McGrannachan CM. 2015 Environmental impact classification for alien insects: a review of mechanisms and their biodiversity outcomes. Curr Opin Insect Sci 12: 46-53. DOI: 10.1016/j.cois.2015.09.004.

Morrill WL, Greene GL. 1973. Distribution of fall armyworm larvae. 1. Regions of field corn plants infested by larvae. Environ Entomol 2 : 195-198. DOI: $10.2307 / 3495644$.

Myers N, Mittermeier RA, Mittermeier CG, da Fonseca GAB, Kent J. 2000. Biodiversity hotspots for conservation priorities. Nature 403 : 853-858. DOI: $10.1038 / 35002501$

Niassy S, Agbodzavu MK, Kimathi E, Mutune B, Abdel-Rahman EFM, Salifu D, Hailu G, Belayneh YT, Felege E, Tonnang HEZ, Ekesi S, Subramanian S. 2021. Bioecology of fall armyworm Spodoptera frugiperda (J. E. Smith), its management and potential patterns of seasonal spread in Africa. PLoS ONE 16: e0249042. DOI: 10.1371/journal.pone.0249042.

Ntiri ES, Calatayud P-A, Van den Berg J, Le Ru BP. 2017. Density dependence and temporal plasticity of competitive interactions during utilisation of resources by a community of lepidopteran stemborer species. Entomol Exp Appl 162: 272-283. DOI: 10.1111/eea.12514.

Ntiri ES, Calatayud P-A, van den Berg J, Le Ru BP. 2019. Spatiotemporal interactions between maize lepidopteran stemborer communities and possible implications from the recent invasion of Spodoptera frugiperda (Lepidoptera: Noctuidae) in Sub-Saharan Africa. Environ Entomol 48: 573-582. DOI: 10.1093/ee/nvz024.

Ntiri ES, Calatayud P-A, Van den Berg J, Schulthess F, Le Ru BP. 2016. Influence of temperature on intra-and interspecific resource utilization within a community of lepidopteran maize stemborers. PLoS ONE 11: e148735. DOI: 10.1371/journal.pone.0148735.

Nwanze JAC, Bob-Manuel RB, Zakka U, Kingsley-Umana EB. 2021 Population dynamics of fall armyworm [(Spodoptera frugiperda) J.E.
Smith] (Lepidoptera: Noctuidae) in maize-cassava intercrop using pheromone traps in Niger Delta Region. Bulletin of the National Research Centre 45: 44. DOI: 10.1186/s42269-021-00500-6.

Paini DR, Sheppard AW, Cook DC, Barro PJD, Worner SP, Thomas MB. 2016. Global threat to agriculture from invasive species. Proc Natl Acad Sci USA 113: 7575-7579. DOI: 10.1073/pnas. 1602205113

R Core Team. 2020. R: A Language and Environment for Statistical Computing. R Foundation for Statistical Computing, Vienna, Austria.

Ren Q, Haseeb M, Fan J, Wu P, Tian T, Zhang R. 2020. Functional response and intraspecific competition in the fall armyworm, Spodoptera frugiperda (Lepidoptera: Noctuidae). Insects 11: 806. DOI: 10.3390/insects11110806.

Rowles AD, O’Dowd DJ. 2007. Interference competition by Argentine ants displaces native ants: implications for biotic resistance to invasion. Biol Invasions 9: 73-85. DOI: 10.1007/s10530-006-9009-5.

Roy HE, Brown PMJ. 2015. Ten years of invasion: Harmonia axyridis (Pallas) (Coleoptera: Coccinellidae) in Britain. Ecol Entomol 40: 336348. DOI: 10.1111/een.12203.

Sartiami D, Dadang, Harahap IS, Kusumah YM, Anwar R. 2020. First record of fall armyworm (Spodoptera frugiperda) in Indonesia and its occurrence in three provinces. IOP Conf Ser Earth Environ Sci 468: 012021. DOI: 10.1088/1755-1315/468/1/012021

Sisay B, Simiyu J, Malusi P, Likhayo P, Mendesil E, Elibariki N, Wakgari M, Ayalew G, Tefera T. 2018. First report of the fall armyworm, Spodoptera frugiperda (Lepidoptera: Noctuidae), natural enemies from Africa. J Appl Entomol 142: 800-804. DOI: 10.1111/jen.12534.

Sokame BM, Tonnang HEZ, Subramanian S, Bruce AY, Dubois T, Ekesi S, Calatayud P-A. 2021a. A system dynamics model for pests and natural enemies interactions. Sci Rep 11: 1401. DOI: 10.1038/s41598-020-79553-y.

Sokame BM, Obonyo J, Sammy EM, Mohamed SA, Subramania S, Kilalo DC, Juma G, Calatayud P-A. 2020. Impact of the exotic fall armyworm on larval parasitoids associated with the lepidopteran maize stem borers in Kenya. Bio Control 66: 193-204. DOI: 10.1007/s10526-020-10059-2.

Sokame BM, Musyoka B, Obonyo J, Rebaudo F, Abdel-Rahman EM, Subramanian S, Kilalo DC, Juma G, Calatayud P-A. 2021b. Impact of an exotic invasive pest, Spodoptera frugiperda (Lepidoptera: Noctuidae), on resident communities of pest and natural enemies in maize fields in Kenya. Agronomy 11: 1074. DOI: 10.3390/agronomy11061074.

Song Y, Yang X, Zhang H, Zhang D, He W, Wyckhuys KAG, Wu K. 2021. Interference competition and predation between invasive and native herbivores in maize. J Pest Sci. DOI: 10.1007/s10340-02101347-6.

Torres-Vila LM, Rodriguez-Molina MC, Lacasa-Plasencia A. 2003. Impact of Helicoverpa armigera larval density and crop phenology on yield and quality losses in processing tomato: developing fruit countbased damage thresholds for IPM decision-making. Crop Protect. 22: 521-532. DOI: 10.1016/S0261-2194(02)00205-3.

Torres-Vila LM, Rodriguez-Molina MC, Lacasa-Plasencia A, Bielza-Lino P. 2002. Insecticide resistance of Helicoverpa armigera to endosulfan, carbamates and organophosphates: the Spanish case. Crop Protect. 21: 1003-1013. DOI: 10.1016/S0261-2194(02)00081-9.

Trisyono YA, Suputa, Aryuwandari VEF, Hartaman M, Jumari. 2019. Occurrence of heavy infestation by the fall armyworm Spodoptera frugiperda, a new alien invasive pest, in corn in Lampung Indonesia. Jurnal Perlindungan Tanaman Indonesia 23: 156-160. DOI: 10.22146/jpti.46455. [Indonesian]

Wiseman BR, McMillian WW. 1969. Competition and survival among the corn earworm, the tobacco budworm, and the fall armyworm. J Econ Entomol 62: 734-735. DOI: 10.1093/jee/62.3.734.

Xiao L, He H-M, Huang L-L, Geng T, Fu S, Xue F-S. 2016. Variation of life-history traits of the Asian corn borer, Ostrinia furnacalis in relation to temperature and geographical latitude. Ecol Evol 6: 51295143. DOI: $10.1002 /$ ece 3.2275

Yu SJ. 1992. Detection and biochemical characterization of insecticide resistance in fall armyworm (Lepidoptera: Noctuidae). J Econ Entomol 85: 675-682. DOI: 10.1093/jee/85.3.675 